\title{
The Rights and Role of Indigenous Women in The Climate Change Regime
}

\author{
Tahnee Lisa Prior* \\ Balsillie School of International Affairs, \\ University of Waterloo, Canada
}

\section{Leena Heinämäki}

Northern Institute for Environmental and Minority Law, Arctic Centre, University of Lapland, Finland

\begin{abstract}
Climate change has direct and indirect consequences for individuals and their human rights (McInerney-Lankford et al. 2011). With the Arctic warming at twice the global rate, its inhabitants already experience many of these challenges. Marginalized groups, like women and indigenous peoples, are particularly vulnerable, with existing research providing evidence of ongoing and potential threats to their roles in community adaptation and in shaping change (Cameron 2011, Arctic Resilience Report 2016). While women's rights are formally codified as human rights under the Convention on the Elimination of Discrimination against Women (CEDAW), and indigenous peoples' human rights are codified and recognized in the UN Declaration on the Rights of Indigenous Peoples (UNDRIP), indigenous women's rights are often neglected at both the international and local level. In this article, we apply an intersectional lens to demonstrate that indigenous and non-indigenous women are agents of change. In doing so, we examine how a human rights based approach might ensure indigenous women's participatory role and legal status in the international climate change regime, as well as its related programs.
\end{abstract}

Keywords: global environmental governance; Arctic; gender; indigenous peoples; intersectionality; human rights

Responsible Editor: Margherita Paola Poto, K.G. Jebsen Centre for the Law of the Sea, UiT The Arctic University of Norway, Tromsø, Norway.

Received: June 2017; Accepted: September 2017; Published: November 2017

${ }^{\star}$ Correspondence to: Tahnee Prior, Balsillie School of International Affairs, University of Waterloo, Canada. Email: tahnee.prior@fondationtrudeau.net. 


\section{T. Prior}

\section{Introduction}

Indigenous peoples and women are two marginalized sub-groups significantly impacted by the unequivocal and accelerating impacts of climate change. While various legal fora slowly awaken to and seek out a better understanding of the impediments to their participation in climate governance, little focus is given to the rights and role of indigenous women in particular.

Although women's rights are formally codified as human rights under the United Nations Convention on the Elimination of Discrimination against Women (CEDAW), ${ }^{1}$ and indigenous peoples' human rights are codified and recognized in the UN Declaration on the Rights of Indigenous Peoples (UNDRIP), ${ }^{2}$ indigenous women's rights are often neglected at both the international and local level. ${ }^{3}$ Yet indigenous women often face systemic violations of their human rights in the context of climate change, experiencing deepened exclusionary and discriminatory practices in their own communities as well as society at large.

In this descriptive article, we argue that the international climate change regime has been slow to integrate indigenous peoples and women into its processes and mechanisms. We apply an intersectional lens to explore how a human rights based approach (HRBA) might ensure indigenous women's participatory role and legal status in the international climate change regime and its related programs. ${ }^{4}$ First, we trace the impact of climate change on women, Arctic indigenous women in particular. Second, we examine the ongoing discourse at the intersection of climate change and human rights, focusing on indigenous women's rights - in relation to women's rights and the rights of Arctic indigenous peoples from a gendered perspective. Third, we trace the intersection of gender and indigeneity within the climate change regime, focusing on the UN Framework Convention on Climate Change (UNFCCC) and some its mechanisms. Finally, we advocate for a stronger role for indigenous women within this context, pointing to some of the participatory challenges which may arise at the intersection of indigenous peoples' and women's rights.

While indigenous peoples' human rights and the climate regime operate at a global level, this article takes an Arctic dimension. The justification is two-fold: the Arctic is changing at an unprecedented rate, with substantive evidence that the region is warming at twice the global rate. ${ }^{5}$ As a consequence, the resilience of the Arctic environment and Arctic indigenous peoples, including Arctic indigenous women, continues to be tested. This article thus provides suggestions for improving indigenous women's legal status in decision-making on climate change.

\section{Gender and Climate Change: A Focus on Women}

Climate change has unequivocal and accelerating implications manifesting in many forms, from large-scale system transformations to localized crop and biodiversity loss. Rising sea levels, storms, and hurricanes lead to direct flooding, the salinization of fresh-water resources, population displacement, and diminished habitable land. ${ }^{6}$ 
Receding coastlines and melting permafrost damage land, homes, and other infrastructure. ${ }^{7} \mathrm{~A}$ loss of glaciers and reduction in snow cover decrease water availability. While all areas of the globe will be affected, some areas like the Arctic are already experiencing acute consequences.

Climate change poses direct and indirect threats to individuals and their human rights, as well. ${ }^{8}$ Negative impacts limit household resources and individuals' ability to meet their daily needs, thereby jeopardizing rights to life, food, water, and housing. The loss of cultural activities, such as traditional livelihoods, can lead to psychological stress, anxiety, and uncertainty for all peoples. ${ }^{9}$

The International Panel on Climate Change (IPCC) projects that "the impact of climate change will fall disproportionately upon developing countries and the poor persons within all countries...". ${ }^{10}$ Already-marginalized groups, including those who are most vulnerable owing to socio-economic factors or lifestyles inextricably linked to nature, will feel the effects most deeply. ${ }^{11}$ Socio-economic factors - economic, social, environmental, geographic, demographic, institutional, and cultural emphasize that not all states, nor subgroups, are placed similarly when it comes to decision-making on environmental governance and climate change. ${ }^{12}$ Thus, while indigenous peoples worldwide have contributed least to carbon emissions, their lives and (traditional) livelihoods, which are inextricably linked to nature, are adversely affected. ${ }^{13}$

Systemic environmental degradation and gender inequality are linked. Both the 2005 and 2007 UN Human Development Reports note that climate change is not only "one of the world's strongest markers for disadvantage"14, but is likely to magnify existing patterns of gender inequality. Moreover, both the Environmental Performance Index of the Yale Centre for Environmental Law and Policy and the World Economic Forum's Global Gender Gap Report highlight that countries vulnerable to climate change are likely to be poorer and have a larger gender gap. ${ }^{15}$ Countries with good environmental performance, on the other hand, tend to rank higher with regard to gender equality. As we will see later on, the northern regions of the eight Arctic states may be an anomaly. Russia aside, all Arctic states maintain high levels of development, but this does not necessarily guarantee gender equality as well. ${ }^{16}$

Broadly, the impacts of climate change highlight lacunae in existing social norms and power structures. ${ }^{17}$ These gaps illustrate that some women are disproportionately impacted for two reasons: 1) historical inequalities and 2) their dependence on sectors and resources that are set to experience intense shifts. ${ }^{18}$

Women generally also face ongoing disadvantages in their access to economic and social resources. ${ }^{19}$ These resources include access to land, financing, new technologies, bargaining power, social capital, and training for climate adaptation and disaster preparedness. ${ }^{20}$ Such inequalities threaten women's resilience to climate change, at times preventing their effective engagement in development processes, and further exacerbating gender inequality. ${ }^{21}$ Low income and a lack of resources, for instance, may affect women's bargaining power at various levels - within households, in 


\section{T. Prior}

communities (including indigenous communities), nationally, regionally, and internationally. ${ }^{22}$ Women's insufficient representation in decision-making processes on climate change mitigation and adaptation can further exacerbate such vulnerabilities. ${ }^{23}$

\section{Impacts of Climate Change on Arctic Indigenous Women}

The impacts of climate change on women, in particular, can be further exacerbated at the intersection of race and gender, thus impacting the lives of indigenous women differently. This is where an intersectional lens that accounts for historical, social, and political context is particularly useful. ${ }^{24}$

Climate change has far-reaching, albeit differentiated, implications for indigenous communities worldwide, including Arctic indigenous peoples. ${ }^{25}$ Although the impacts vary substantially, even within the same region or state, commonalities exist with regard to indigenous peoples' experience of climate change, and its consequences for indigenous lands and traditional livelihoods; often leaving them both physically and legally vulnerable to its effects.

Both indigenous peoples in the Arctic and in low-lying coastal states face changes in biodiversity that threaten food security. ${ }^{26}$ Arctic indigenous peoples such as the Inuit are "now being severely tested" as their fundamentally nature-based way of life is altered as a result of climate change, making its impacts a human rights issue. ${ }^{27}$ As John Knox, the United Nations Special Rapporteur on human rights and the environment, has noted, substantial investment will be necessary to adapt or relocate physical structures and communities. ${ }^{28}$ Based on the Arctic Climate Impact Assessment, climate change will accelerate, contributing to major physical, ecological, social and economic changes, many of which are already taking place. ${ }^{29}$ Indigenous people, the elderly, women, and children are considered particularly vulnerable groups in Arctic communities. ${ }^{30}$

Moreover, while indigenous peoples have contributed least to climate change, research shows that they are likely to be the first and most affected, have little leverage at negotiating tables in comparison to major actors and emitters, are least likely to be the beneficiaries of complex climate funding, and are often improperly consulted during project implementation. ${ }^{31}$

On-going dispossession, marginalization, acculturation, and discrimination are amplified by changing environmental conditions. A rise in negative developments and inter-group conflict may occur when climate stressors exacerbate existing social, economic and political factors. Climate change, at its most catastrophic level, includes "the total destruction of an indigenous community's identity and distinct way of life."

The loss of indigenous peoples' ability to continue their livelihood, and disappearance as a whole, would be a loss to society, especially as indigenous communities are considered to be repositories of knowledge and skills, ${ }^{33}$ such as multiple species management and resource rotation. ${ }^{34}$

As such, Arctic indigenous peoples are increasingly drawing on a HRBA. Two examples in an Arctic context stand out. In 2005, the Inuit, under the leadership of 
Sheila Watt-Cloutier, brought a human rights petition to the Inter-American Commission on Human Rights. ${ }^{35}$ The Inuit Petition was raised against the United States, the world's largest emitter of greenhouse gases at the time. Cloutier argued that consequences resulting from US actions, as opposed to direct interference on indigenous lands, was having adverse impacts on an already marginalized group and their human rights. While the Inter-American Commission did not proceed with the case, the Inuit Petition highlighted the link between climate change and human rights, challenging existing human rights bodies while broadening the scope of climate change debates. A similar petition was brought to the Inter-American Commission by Ruth Massie and the Arctic Athabaskan Council in 2013; raised against Canada for its failure to regulate its black carbon emissions, linked climate change. ${ }^{36}$ The Commission has not proceeded with the Petition. Similar to the Inuit Petition, it may have proved challenging for the Commission to identify human rights infringements as a direct result of a global environmental problem.

The global nature of climate change, as illustrated by these two Petitions, makes it difficult for indigenous peoples to seek the protection of their substantive rights through traditional human rights mechanisms. Within this already discriminatory context, indigenous women often face further systemic violations at the nexus of gender and indigeneity. ${ }^{37}$ Indigenous women are particularly vulnerable to the impacts of climate change ${ }^{38}$ due to geography, land rights and ownership, and patriarchal structures, among other factors. A key concern includes their right to territory and natural resources, which are "inextricably linked to [their] survival, development, identity, and self-determination.” 39

\section{When Climate Change and Human Rights Intertwine}

We argue that international law could help indigenous communities, including indigenous women, protect themselves by providing them with the opportunity to shape analysis and decision-making processes, design instruments and substantive outcomes, draw attention to climate change vulnerability, and trigger more effective responses. ${ }^{40}$ The genuine participation of indigenous communities can minimize negative impacts like human rights violations, and maximize positive outcomes that are in line with indigenous communities' interests and values. But first, we must examine the interaction of climate change and human rights discourse to date.

As we can see from the examples above, translating the implications of climate change into human rights language is often regarded as creative interpretation based on ethical and moral import and is thus avoided in current policy-making. ${ }^{41}$ In the climate regime, procedural fairness, environmental justice, and arguments for immediate climate change action have emerged as important principles without reference to human rights; thereby often disregarding the vulnerability of marginalized groups. ${ }^{42}$

While the climate regime has been slow to adopt a rights-based approach, human rights institutions increasingly consider climate change as a human rights issue, as 


\section{T. Prior}

opposed to an environmental issue per se. Human rights monitoring bodies increasingly recognize the undisputed implications of climate change on individual wellbeing and the normative traction that human rights language has on strong mitigation and adaptation policies. ${ }^{43}$

The notion of a (non-binding) right to a safe and healthy environment continues to surface on the agendas of international human rights bodies, giving credence to the claim of its recognition. ${ }^{44}$ The 2009 Human Rights Council consensus Resolution $10 / 4$ on human rights and climate change recognizes that individuals are of a central concern to sustainable development, finding that "human rights obligations and commitments have the potential to inform and strengthen international and national policymaking in the area of climate change, promoting policy coherence, legitimacy and sustainable outcomes." 45 The Office of the High Commissioner of Human Rights (OHCHR) has similarly mapped the consequences of climate change on human rights, highlighting that human rights bodies recognize "the intrinsic link between the environment and the realization of a range of human rights." 46 Furthermore, it emphasizes that legal duties concerning climate change, such as access to information and participation in international cooperation and decision-making, are grounded in human rights law.

At the $21^{\text {st }}$ meeting of the Conference of the Parties to the UNFCCC (2015), the OHCHR stressed that efforts to address climate change should not exacerbate inequalities within or between States. Thus, according to the OHCHR, indigenous peoples' rights should be fully reflected in line with UNDRIP, and actions likely to impact their rights should not be taken without their free, prior and informed consent (FPIC). ${ }^{47}$ Importantly, the OHCHR further emphasized that efforts to ensure gender equality should be included in all planning for climate change mitigation and adaptation. Additionally, the rights of children, older persons, minorities, migrants and others in vulnerable situations must be effectively protected. ${ }^{48}$ Significantly, the $\mathrm{OHCHR}$ has called for a human rights-based approach in fighting climate change. ${ }^{49}$

More recently, in 2016, John Knox published a study on human rights obligations relating to climate change..$^{50}$ The study highlighted that the foreseeable adverse effects of climate change on the enjoyment of human rights gives rise to State duties to protect against those effects. Human rights obligations not only apply to decisions about how much climate protection to pursue, but also to the mitigation and adaptation measures through which the protection can be achieved. ${ }^{51}$ His study raises a special concern regarding vulnerable groups - like women and indigenous peoples - to environmental harm. ${ }^{52}$ States, he argues, should ensure that those who are vulnerable and marginalized are fully informed of the effects of climate actions; that they are able to participate in decision-making processes and are protected in developing and implementing climate-related actions because even when mitigation targets are met, vulnerable communities can still suffer harm as a result of climate change. ${ }^{53}$

In his earlier research, Knox noted that, although the link between climate change and human rights may seem self-evident, the "specific contours of substantive and 
procedural duties relating to the environment require further clarification." 54 Discourse surrounding a human right to a clean environment has existed for many years. ${ }^{55}$ Case law connecting human rights and the environment, for instance, exists both at the regional and international level. ${ }^{56}$ More recently, we have seen a shift in the discourse. While early debates focused on the vagueness of a right to a safe, decent, or healthy environment, more recent conversations centre on the distinction between substantive and procedural human rights to a clean environment. ${ }^{57}$ The World Commission on Environment and Development, for instance, recognizes:

the right of individuals to know and have access to current information on the state of the environment and natural resources, the right to be consulted and to participate in decision-making on activities likely to have a significant effect on the environment, and the right to legal remedies and redress for those whose health or environment has been or may be seriously affected..$^{58}$

A joint OHCHR and United Nations Environment Program report on Human Rights and the Environment, too, regards environmental protection and the promotion of human rights as a fundamental pillar of sustainable development. ${ }^{59}$ The promotion of human rights can, in turn, provide opportunities for local communities to participate in decision-making processes.

It is increasingly obvious that international human rights and climate policies stand to gain from cross-fertilization in addressing the human and equity dimensions of climate change. ${ }^{60} \mathrm{~A}$ HRBA can empower vulnerable groups as agents in the design and implementation of adaptation policies, in setting national and international mitigation targets, and holding decision-makers accountable. ${ }^{61}$ At the same time, the consistent pursuit of both policy areas may face challenges for three reasons: 1) indirect concerns for the environment; 2) the limited capacity of both state and non-state actors to partake in a HRBA due to a lack of time, expertise, information, or funding; and 3) and the danger of a simple rhetorical repackaging of aid policies without the application of human rights principles. ${ }^{62}$

\section{Indigenous Women's Rights and Climate Change}

Indigenous women can play crucial roles in strengthening existing processes related to climate change. However, without proper and consistent arrangements for their participation, indigenous women must often turn to a mosaic of local organizations, as well as national and international networks for the protection of their human rights.

Indigenous women's rights fall both within the legal framework of women's rights and indigenous peoples' rights. However, "[d] ue to colonization and on-going imperial influences," Laura Parisi and Jeff Corntassel argue, "both women's rights and indigenous rights movements have been problematic spaces for indigenous women's participation." 63

Still, there is little international literature or activism on the rights of indigenous women and the challenges they face in their communities, including: stereotypes, 


\section{T. Prior}

pre-determined roles, and harmful practices. ${ }^{64}$ Some indigenous activists and scholars, for instance, regard indigenous practices and stereotypes of indigenous women as taboo. ${ }^{65}$ Sarah Radcliffe confirms that issues of gender remain secondary to the cultural politics of indigenous movements, where "the persistence of a complementary dual model of gender underpins a traditional and symbolic role for indigenous women." 66

Below, we aim to outline the rights of indigenous women in terms of women's rights and gendered perspectives on indigenous rights in the context of climate change. Particular focus is placed on the tensions that may arise between women's individual and collective rights.

\section{a. Women's Rights and Climate Change}

While principles of equality, including gender equality, are enshrined in major human rights instruments, international environmental legal instruments have paid little attention to the role of women in protecting the environment or in promoting sustainable development. Major human rights instruments include the principles of the Universal Declaration of Human Rights, which prohibit gender discrimination and recognize women's rights to equality before the law. ${ }^{67}$ The International Covenant on Civil and Political Rights further prohibits discrimination and promotes the equality of women's and men's rights and equality before the law. ${ }^{68}$ Furthermore, the International Covenant on Economic, Social and Cultural Rights, in a similar manner, prohibits discrimination, calling for the equality of women and men with regard to the rights recognized by the Covenant. ${ }^{69}$

The United Nations CEDAW, in particular, obliges state parties to secure the fundamental human rights - economic, social, cultural, civil and political rights and freedoms of women by aligning policies with its provisions. ${ }^{70}$ CEDAW obliges parties to ensure the inclusion of women across all aspects of development planning, including rights to participation, land ownership, resources, livelihoods, education and safety; all of which are relevant for climate change policy. ${ }^{71}$ Although references to gender and the participation of women in policy development and implementation are limited in CEDAW, ${ }^{72}$ its provisions are understood to guarantee women's rights to equal treatment before the law, and to ensure women's participation when deciding on mitigation and adaptation policies, as well as other mechanisms like the fair distribution of funds, technology, and information.

In 2009, members of the CEDAW Committee adopted climate change as an urgent issue. It calls on parties to include gender equality as a guiding principle in drafting future international climate change agreements and to "ensur[e] that climate change and disaster risk reduction measures are gender responsive, sensitive to indigenous knowledge systems and respect human rights. Women's right to participate at all levels of decision-making must be guaranteed in climate change policies and programmes."73

More recently, in 2016, the CEDAW Committee's work on gender was furthered by a public discussion, organized with $\mathrm{OHCHR}$, on gender-related dimensions of disaster 
risk reduction and climate change in the context of the provisions of the CEDAW, with the purpose to prepare a "General Recommendation on gender-related dimensions of disaster risk reduction and climate change". ${ }^{74}$ The CEDAW Committee highlighted that climate change and disasters affect women and men, girls and boys differently, with many women experiencing disproportionate risks and impacts from disasters and climate change. Situations of crisis exacerbate pre-existing gender inequalities and also compound intersecting forms of discrimination that affect some women differently than other women and men. Discriminatory barriers which limit many women's equal access to education and information, capital, property, land and productive resources, civil and political rights, legal and justice systems, health care, adequate housing, employment and social protection, increase their exposure to the negative effects of climate change and disasters. These same obstacles also prevent women's ability to actively contribute to decision-making and the development of activities related to climate change mitigation, disaster prevention and reconstruction efforts. ${ }^{75}$

\section{b. Gender Perspectives on the Rights of Arctic Indigenous Peoples}

The current pace and impact of climate change is beyond indigenous adaptive capacity - amplifying dispossession, marginalization, acculturation, and discrimination and threatening indigenous peoples' general human rights. Their right to culture and traditional way of life are under immediate and direct threat. ${ }^{76}$ Despite some positive impacts, mitigation and adaptation projects can also have numerous adverse effects on indigenous livelihoods and rights.

Within this context, little attention has been given to how indigenous women experience human rights violations at the intersection of both individual and collective identities. ${ }^{77}$ Tension between the indigenous movement and the international women's rights movement is located in the international women's movement's "overemphasis on gender discrimination and gender equality which depoliticizes issues confronting indigenous women" and lack of recognition of the special circumstances of indigenous women. ${ }^{78}$ This is reflected in indigenous women's criticism of the Beijing Platform for Action (1995). ${ }^{79}$ For instance, as Rauna Kuokkanen reminds us, the systemic violation of indigenous women's rights puts indigenous collective rights at risk, as well. ${ }^{80}$

Since the adoption of the UNDRIP in 2007, concerns relating to indigenous women are increasingly prominent. CEDAW, on the one hand, does not refer to indigenous women or contain a provision for prohibiting racial discrimination. Moreover, its Committee has shown little interest in the issue, and has not undertaken a systematic review of the situation. In 2014, however, several indigenous women's organizations put forward a proposal to the CEDAW Committee to make a general recommendation on the individual and collective rights of indigenous women; and to implement special measures to ensure that the life, rights, and dignity of indigenous women in different parts of the world are not violated, damaged, or jeopardized. ${ }^{81}$

UNDRIP, on the other hand, focuses on the role of indigenous women in numerous articles. Article 21 emphasizes that states should take effective measures to 


\section{T. Prior}

ensure the improvement of economic and social conditions for indigenous peoples, including indigenous women; ${ }^{82}$ Articles 21.2. and 22 further advise states to take special measures to ensure the protection of the rights of indigenous women, among other vulnerable groups, against violence and discrimination; ${ }^{83}$ and Article 44 recognizes the responsibility of state parties to guarantee the rights and freedoms, as recognized in the Declaration, to indigenous male and indigenous women alike. ${ }^{84}$ Still, gender often remains an aside in discourse on the Declaration.

The UN Permanent Forum on Indigenous Issues (UNPFII) - an advisory body to the Economic and Social Council focusing on indigenous issues related to the environment, and human rights, among other issue areas - is active in mainstreaming the rights of indigenous women. ${ }^{85}$ At its Sixth Session, UN PFII requested an investigation and subsequent report on "the impacts of mitigation measures on indigenous peoples." 86 The report noted that,

shared but differentiated responsibilities, equity, social justice and sustainable development, must remain as key principles that sustain climate change negotiations, policies and programmes. The approach to development and the ecosystem, based on human rights, should guide the design and implementation, at national, regional and global levels, of policies and projects on climate. ${ }^{87}$

It also recognized "[t]he crucial role of women and indigenous girls in developing mitigation and adaptation measures." Such articulations remain contested, however. As Kuokkanen argues,

the conception of indigenous peoples' rights as human rights, on the one hand, and as both individual and collective rights, on the other, exposes the double-standard in domestic politicized rhetoric that opposes indigenous women's rights as individualistic and in conflict with collective rights. ${ }^{88}$

Particular difficulties arise in reconciling UNDRIP provisions prohibiting discrimination with those relating to self-determination. Some, in turn, argue that inherent collective rights can lead to the oppression of individual indigenous rights. ${ }^{89}$ Rights conflicting with gender equality, in accordance with the Declaration, include the right to define the responsibilities of the individual to the community, apply customary law, regulate community affairs, and choose representatives to participate in decision-making.

Throughout the process of adopting UNDRIP, states focused on possible violations of such individual rights where women might suffer from group power. ${ }^{90}$ Striking a balance between individual and collective rights in a manner that enhances cultural integrity, while securing the integrity of women's rights, is a challenge requiring open-mindedness, and a willingness to compromise, adapt, and commit.

Although literature on indigenous peoples' right to self-determination is increasing, less attention is given to the gender dimension of indigenous self-determination. ${ }^{91}$ This is problematic because indigenous self-determination often "conceals patriarchal 
structures and relations of power, which create hierarchical and differential access to resources, representation, political influence, and to being heard in indigenous societies." ${ }^{\prime 92}$

As Kuokkanen notes,

[f] or many indigenous women, self-determination is crucial both at individual and collective levels, and neither should be compromised in the name of the other. Individual self-determination is considered a condition for sustainable and strong collective self-determination. Survival, for indigenous women, is both an individual and collective matter. ${ }^{93}$

Tensions between indigenous and women's rights have arisen when "indigenous women advocating their rights have been repeatedly accused of being disloyal to their communities, corrupted by 'Western feminists,' and of introducing alien concepts and thinking to indigenous communities and practices." ${ }^{94}$ In a Canadian context, some indigenous women mobilized to advance their human, civil, and political rights in the 1970 s to end gender discrimination and violence in their communities. This led to the creation of numerous local, reserve-based groups and national organizations. ${ }^{95}$ However, their mobilization was poorly received by indigenous male leadership, criticized for being "anti-Indian" and a betrayal of self-determination, as well as being co-opted into "colonial Western discourses of individualism." ${ }^{96}$ Similar cases often arise in the context of deforestation, where gender inequality continues in forest management despite long-standing conventions, treaties, and other instruments.

The consequences of this may play out as follows: a framework for women's property rights that emphasizes individual rights of possession over indigenous peoples' rights might lead to the loss of indigenous peoples' land violating the rights of both indigenous peoples and indigenous women in particular.

Unlike other indigenous women who explicitly reject indigenous selfdetermination which replicates dominant and patriarchal structures, Sámi women have not always mobilized to change existing political structures toward indigenous values and philosophies. ${ }^{97}$ Still, other Sámi women criticize self-determination processes, noting that collective self-determination should take place locally, rather than through centralized institutions like the Sámi parliaments, which can have a "paralyzing effect". ${ }^{98}$

\section{Intersecting Gender and Indigeneity in the Climate Regime}

The discourse on climate change remains gender blind, fragmented, superficial, inconsistent, partially implemented, and limited to short-term interventions. ${ }^{99}$ Moreover, discourse on intersectionality with regard to how already-marginalized groups like indigenous women experience climate change is thin, albeit growing. In the general outline below, we take a descriptive approach to the integration of human rights discourse relating to gender and indigeneity into the climate change regime, focusing on some UNFCCC policies and processes in particular. 


\section{T. Prior}

\section{a. Integrating Gender into the UNFCCC}

The international climate change regime has been particularly slow to systematically integrate gender into its policies and processes, often adding women as an afterthought, with their needs addressed sporadically. As an example, processes and mechanisms of the UNFCCC, like the Kyoto Protocol ${ }^{100}$, failed to reference gender until recently. ${ }^{101}$ Over time, both the IPCC and state parties to the UNFCCC have increasingly recognized and adhered to human rights frameworks, standards, as well as international and national commitments on gender equality; recognizing that gender is a key factor in shaping vulnerability. ${ }^{102}$ Below we outline some of the watershed moments.

Beginning in 2007 with the Bali Action Plan, and emerging from COP 13, ${ }^{103}$ conversations on gender and climate change began to increasingly take place within the UNFCCC. At COP 14 in 2009, the UNFCCC advocated for "formulating gender inclusive policy measures in addressing climate change" 104 and formally recognized women's civil society groups as a Provisional Constituency. Gendered language appeared in UNFCCC documents at COP 15, as well. These documents acknowledged that, "the effects of climate change will be felt most acutely by those parts of the population that are already vulnerable"; highlighted the need for "gender equality and the effective participation of women"; and called for "gender sensitivity and consideration in efforts on adaptation, capacity building, and deforestation." 105 Decisions taken in 2010 and 2011, at COP 16 and COP 17 respectively, continued on the same trajectory; ${ }^{106}$ the Cancún Agreement and the 2011 decision text of the Green Climate Fund both included a gender dimension. ${ }^{107}$ COP 18 in Doha in 2012 further adopted a decision to promote "gender balance and improve the participation of women in UNFCCC negotiations and in the representation of Parties in bodies established pursuant to the Convention or the Kyoto Protocol," a significant step in advocating for gender in climate policy. ${ }^{108}$

COP 19 in 2013 included a range of gender-related side events, like a designated Gender Day and the launch of the Environmental Gender Index, a project of the International Union for Conservation of Nature (IUCN). ${ }^{109}$ Under its draft conclusion, the Subsidiary Body for the IUCN agreed to "consider ways that gender balance, gender-sensitive climate policy and the effective participation of women in the work of bodies under the Convention and its Kyoto Protocol could be strengthened." UN Women also stressed that the world cannot afford to ignore the voices, needs, and priorities of women in climate adaptation and mitigation, in global discussions or in actions on the ground. ${ }^{111}$ Ultimately, the most effective outcome at COP 19 (2013) was the number of actors who engaged with the issue of gender and climate change. ${ }^{112}$

Some argue that the UNFCCC took a significant step away from its gender blindness, at inception ${ }^{113}$, by passing a decision to launch the Lima Work Programme on Gender at COP 20 (2014), ${ }^{114}$ a two-year work programme to promote gender balance and achieve gender-responsive climate policy to guide the effective participation of women in the bodies set up under the convention. ${ }^{115}$ 
COP 22 (2016) adopted a decision on gender and climate change, ${ }^{116}$ noting that gender-responsive climate policy requires further strengthening of all activities concerning adaptation, mitigation, and related means of implementation, as well as decision-making on the implementation of climate policies. ${ }^{117}$ The same year, the UNFCCC secretariat organized a workshop on gender responsive climate policy with a focus on adaptation, capacity-building, and training for delegates on gender issues. ${ }^{118}$

Despite these developments, the original climate regime does not place a strong focus on gender in mitigation and adaptation policies because it does not provide a legal framework or a HRBA. ${ }^{119}$ Still, its guide for National Adaptation Plans of Action does refer to gender, although many national reports only generally address the vulnerability of women and do not recognize women as agents in adaptation. ${ }^{120}$ Similar to other institutions, both the UNFCCC and its National Adaptation Plans of Action portray women as victims "without the skills that would allow them to become involved in negotiations or strategic planning." 121

However, a gender perspective was strengthened with the Paris Agreement ${ }^{122}$ at COP 21, in 2015, and Decision 1/ CP 21. ${ }^{123}$ In its Preamble, the Parties acknowledged that climate change is a common concern of humankind. And when taking action to address climate change, Parties should respect, promote, and consider their respective obligations on human rights, the right to health, the rights of indigenous peoples, local communities, migrants, children, persons with disabilities and people in vulnerable situations and the right to development, as well as gender equality, empowerment of women and intergenerational equity. Article 7 (paragraph 5) of the Paris Agreement further acknowledges that adaptation actions should follow a gender-responsive, participatory, and fully transparent approach, taking into consideration vulnerable groups, communities and ecosystems. It also recognizes the role of indigenous peoples' traditional knowledge alongside scientific knowledge. Article 11 (paragraph 2), regarding capacity-building, also emphasizes the need of related processes to be interactive, effective, participatory, cross-cutting, and gender-responsive. The gender perspective is further noted in Paragraph 102 of Decision 1/CP. 21 related to the composition of the meeting of the parties. It decides that the selection must account for gender balance in addition to geographical representation. ${ }^{124}$

\section{b. Women's Participation at the UNFCCC}

Between 2008 and 2012, an average of 32 per cent of national delegations and 23 per cent of Heads of Delegations (per year) at the UNFCCC were women. ${ }^{125}$ In 2012, there were an average of 5 all-female delegations, while there were an average of 34 all-male delegations. ${ }^{126}$ Since 2012, as mandated by Decision 23/CP.18, ${ }^{127}$ "promoting gender balance and improving the participation of women in UNFCCC negotiations and in the representation of Parties in bodies established pursuant to the Convention or the Kyoto Protocol," the UNFCCC secretariat issues annual reports on gender composition prior to COP sessions to track progress in advancing the goal of gender balance in UNFCCC bodies and party delegations. ${ }^{128}$ 


\section{T. Prior}

The 2016 report of the Secretariat noted an increase in women's representation in 4 out of 12 constituted bodies set up under the Convention and its Kyoto Protocol, when compared to the previous year. ${ }^{129}$ Meanwhile, women's representation remained unchanged in five bodies and decreased in three. ${ }^{130}$ Women delegates made up 30 per cent or more of the membership for seven of the bodies, with representation as low as 10 per cent in the Compliance Committee, for instance. ${ }^{131}$ The report further notes that six women were elected as chair or co-chair of a constituted body, and three as vice-chair. ${ }^{132}$

While women's overall involvement continues to increase, women continue to lack entry points to share knowledge and participate in decision-making. For instance, women's participation does not necessarily translate into women's involvement on the ground.

\section{c. Indigenous Peoples and the Climate Change Regime}

Although indigenous peoples are regarded as a distinct legal category - quasi-state actors with special rights and status within many individual states ${ }^{133}$ - this does not reflect their position in international norm-making. Indigenous peoples do not constitute states and, in most cases, have no ambition of statehood, with most working to establish some form of self-governance within existing nation states. Without state status, however, indigenous peoples are excluded from international law-making processes in matters that directly affect their interests and rights, including the context of climate change. ${ }^{134}$ It can be argued that the intermediate position of indigenous peoples, representing peoples within states, should be reflected in their status in international treaty-making too. ${ }^{135}$ Moreover, their right to self-determination and their right to participate effectively form an integral part of indigenous rights to culture as recognized by several widely ratified human rights instruments, including the international human rights covenants ${ }^{136}$ and the International Convention on the Elimination of all Forms of Racial Discrimination (1965). ${ }^{137}$

As such, an International Forum of Indigenous Peoples on Climate Change (IFIPCC) was established as a caucus of indigenous peoples at the UNFCCC. Since its inception in 2000, IF-IPCC has called on the COP to acknowledge the special status of indigenous peoples, provide financial support, and requested that decisions on the implementation of the Kyoto Protocol include provisions recognizing the fundamental rights of indigenous peoples. ${ }^{138}$

In response to a 2003 Report by the UNPFII, which outlined 13 recommendations on the intersection of climate change and indigenous peoples, the UNFCCC Subsidiary Body for Implementation noted that "opportunities exist for fostering a full and effective participation by indigenous peoples' organizations in the Convention process. It requested the secretariat to convey its conclusions to the Permanent Forum on Indigenous Issues." ${ }^{\prime 139}$ However, no mention was made regarding indigenous women in particular. 
A 2010 declaration recommended the formal representation of indigenous peoples through the creation of an "Indigenous Peoples Advisory Group" which would provide opportunities for greater input in negotiations. With regard to financial support, a report commissioned by the Secretariat to the Stakeholder Forum for a Sustainable Future recommended the development of a voluntary fund similar to that of the CBD, which "developed mechanisms to enable the participation of indigenous and local communities in formal and informal meetings, and their representation on an Advisory Committee." 140 The 2010 Cancun agreements, produced under the auspices of the UNFCCC, further stipulated that all Parties "should, in all climate change-related actions, fully respect human rights". ${ }^{141}$

In 2012, indigenous peoples' representatives called for the implementation of four proposals to strengthen indigenous representation similar to those proposed by the IF-IPCC in 2000. Indigenous women were not highlighted.

A more specific safeguard regarding indigenous human rights has been defined in the context of REDD+, a mechanism at the center of global and national climate mitigation strategies. The mechanism provides incentives for reducing emissions from deforestation and forest degradation in developing countries by creating financial value (such as financial compensation) for carbon stored and absorbed by forests, providing developing countries with funding for limiting deforestation and forest degradation. Its safeguard, more specifically, calls for the respect of indigenous knowledge and rights in accordance with international obligations and national laws, including UNDRIP. ${ }^{142}$

As such, since its inception, REDD+ has generated great interest as a possible means of strengthening community land and resource rights, empowering community institutions, increasing income through benefit-sharing, and supporting indigenous peoples' and local communities' forest stewardship activities.

At the same time, REDD+ initiatives can further exacerbate inequality in terms of women's access and control over land, forests, and natural resources. REDD+ is problematic because it focuses on the link between carbon credits and the reduction of deforestation, yet women are less likely to be responsible for deforestation and forest degradation in the first place. Moreover, women often have no ownership rights, making them ineligible to receive carbon credits or other benefits from REDD+.

\section{d. Indigenous Women in UNFCCC Processes}

The Arctic Council's 2002 Inari Declaration recognized "the crucial role of women in developing viable Arctic communities" and encouraged "the integration of gender equality and women and youth perspectives in all efforts to enhance human living conditions in the Arctic." 143 We, too, believe that a HRBA to the climate change regime can advance the participation of, and provide effective remedies for, indigenous women. ${ }^{144}$ Why? Because a human rights framework places gender inequality into a broader context that engages with both oppression and privilege, ${ }^{145}$ shifting the conversation to women's fundamental rights. ${ }^{146}$ 


\section{T. Prior}

\section{Participation}

The Arctic Human Development Report highlights two dimensions of thought regarding gender in an Arctic context. One recognizes that a better understanding of traditional knowledge can build awareness of what may be lost when adopting gender roles from other cultures. ${ }^{147}$ The second acknowledges that issues surrounding women's representation in formal decision-making structures are a part of western, non -western, and indigenous feminist perspectives. ${ }^{148}$

International processes and policies regarding climate mitigation and adaptation, including UNFCCC processes like REDD+, often force indigenous women to choose between "artificial boxes" - between being "woman" or "indigenous" - with the purpose of "moving forward". ${ }^{149}$ Neither women nor indigenous peoples are homogenous groups, however, and such silos can act as barriers to change.

While women within indigenous movements should also serve as representatives, this mold is particularly difficult to break when patriarchal systems of representation, thinking, and law often call on women to align with indigenous peoples' movements, at times led by indigenous men. ${ }^{150}$ As Kuokkanen notes, this is visible locally in the structural inequality of traditional economies like reindeer herding, where Sámi women have been pushed to the margins. ${ }^{151}$ It is also the case in UNFCCC processes, where indigenous voices, and indigenous women's voices in particular, remain largely muted - and where they are primarily regarded as stakeholders, not rights holders. ${ }^{152}$

If indigenous peoples are given a stronger position in international environmental decision-making, using the "permanent participant" model of the Arctic Council"153 for instance, the question of who should represent indigenous peoples arises. One possibility would be for the UNPFII to act as a representative body, bringing the "indigenous voice" to decision-making. ${ }^{154}$ This would be particularly effective as the UNPFII has already highlighted the participation of indigenous women in decisionmaking concerning climate change.

Furthermore, Arctic indigenous peoples' organizations, especially the Inuit Circumpolar Council and Sámi Council, have actively participated in its work. ${ }^{155}$ Together, they formed an Arctic Caucus, making statements concerning climate change at the Seventh Session of the UNPFII. ${ }^{156}$ They recommended that the UNFCCC develop a seat for indigenous peoples at the negotiating table, which would provide direct access to decision-makers and an opportunity to share their knowledge in constructive ways. ${ }^{157}$ The participation of indigenous women in this context would be of high value. What is more, Arctic states should also develop participatory quotas for indigenous women, who are particularly underrepresented in high-level political positions on a global scale. This might include the active support of indigenous women in national delegations

\section{FPIC}

The participatory rights of indigenous peoples, including indigenous women, in UNFCCC processes should also be understood as important when considering 
that their collective land-holding is critical to sustaining cultural and spiritual traditions.

Recent developments relating to indigenous peoples in international law strongly support their inclusion in matters directly affecting their rights and interests. The adoption of UNDRIP, in particular, marked a paradigm shift in state-indigenous relations, universally. ${ }^{158}$ In line with the development of indigenous peoples' legal status - from legal objects toward legal subjectivity - over the past few decades; ${ }^{159}$ it is crucial that indigenous peoples be fully informed of the consequences of the use and exploitation of natural resources in their lands and territories. Often, this takes place through consultations; free, prior and informed consent (FPIC); environmental impact assessment; and socio-cultural impact assessments.

The right to FPIC - a crucial part of self-determination - is clearly demonstrated in UNDRIP provisions relating to the use of natural resources. ${ }^{160}$ While concepts like FPIC are broadly accepted in UNFCCC processes, such as REDD+, difficulties in its operationalization challenges its practical adoption. The concept becomes even more ambiguous when it no longer refers to consent, but consultation instead. As such, it may facilitate the widespread violation of indigenous peoples' rights; including collective rights, land rights, ownership rights to natural resources, and the right to self-determination. What is more, research on the role of indigenous women within this context - relation to FPIC and REDD+ - remains scarce.

Tenure rights, in addition to rights and responsibilities in controlling, accessing, and managing resources, are "key to understanding local social contexts, perceptions, and concerns." "161 The gendered dimension of property and tenure rights, moreover, is complex (distinctions between ownership to particular resources, for instance) and mediated by legal constructs like customary and statutory laws or project-based rules, which often vary regionally. ${ }^{162}$

The recognition of indigenous women's rights is particularly important, even problematic to some, when women's property rights are provided through secure titles to forest resources; thereby problematizing the ability of indigenous peoples to maintain collective control over their territories. Issues of land ownership and tenure must be resolved prior to agreements in order to prevent the exacerbation of land conflicts resulting from increased economic value attached to particular goods. In the context of forestry, issues regarding tenure must be addressed in an effort to secure the recognition of women's rights to forest products and carbon offsets. It is thus crucial to align the incentives of investors and local communities; "ensuring tenurial security for women in particular would provide [a] higher degree of confidence in the alignment of those incentives." 163

Still, gender issues often remain outside participatory schemes. A lack of knowledge regarding the gender dimension of customary tenure rights of local communities in projects like REDD+ can have significant consequences.

In the context of the Arctic, issues of gender equality must be understood from a uniquely northern perspective in a manner that does not reinforce colonial 


\section{T. Prior}

attitudes. ${ }^{164}$ The 2004 AHDR highlights women's poor representation in "many formal decision-making bodies, especially in natural resources management, which provides the socio-economic base for many Arctic communities." ${ }^{165}$ Such mechanisms reveal prevailing gender injustice as the underlying problem of indigenous women's human rights. ${ }^{166}$

\section{Conclusions and Recommendations}

Although human rights monitoring bodies and institutions increasingly recognize that the consequences of climate change have undisputed implications for individuals' wellbeing and fundamental human rights, and even though the rights of indigenous peoples and women's rights are codified in international human rights law, the UNFCCC has been slow to integrate indigenous peoples and women into climate-related processes and mechanisms. As shown in this article, attempts exist to improve the situation, especially over the past two years. Generally speaking, however, the situation has not improved substantially.

Moreover, at the intersection of gender and race, indigenous women often fall by the wayside, particularly when it comes to participatory rights and in relation to tenure rights within existing climate mechanisms.

In this descriptive paper, we provide a detailed account of the integration of gender and indigenous peoples within UNFCCC processes, arguing that the adoption of a HRBA - placing gender inequality into a broader context that engages with oppression and privilege - can advance the participation of, and provide effective remedies for, indigenous women. ${ }^{167}$

Consequently, Arctic states should encourage a HRBA that accounts for indigenous self-determination and indigenous women's social, economic, civil and political rights. Arctic states should also develop participatory quotas for indigenous women, who are particularly underrepresented in high-level political positions on a global scale. This might include the active support of indigenous women in national delegations; or alternatively, a push for a permanent seat (represented by the UN Permanent Forum on Indigenous Issues), with a quota for indigenous women, in UNFCCC processes.

\section{ACKNOWLEDGEMENTS}

A significant portion of this research was commissioned and funded by the Finnish Ministry For Foreign Affairs (MFA) for a project on how Finnish Foreign Policy can help address the climate vulnerability of indigenous peoples and women through participatory rights. The research is, however, extended, updated and followed up by developments after the project that was conducted 2013. In this regard we would like to thank the co-authors of that report - Sebastien Duyck, Adam Stepien, and Timo Koivurova - for their support and constructive feedback. We would especially like to thank 


\section{The Rights and Role of Indigenous Women in The Climate Change Regime}

Sebastien Duyck for inspiring this research. His research contribution on procedural rights in international environmental governance and the climate change regime has been particularly helpful in our research. Finally, we would like to thank Rauno Merisaari, Finland's Human Rights Ambassador to the MFA for his support in the realization of this project. We would also like to thank Harsh Barala for his editorial assistance.

\section{NOTES}

1. Convention on the Elimination of All Forms of Discrimination against Women, adopted 18 Dec. 1979, G.A. Res. 34/180, U.N. GAOR, 34th Sess., U.N. Doc. A/34/46 (1980), 1249 U.N.T.S. 13 (entered into force 3 Sept. 1981).

2. UNDRIP emphasizes it equal application to both "male and female indigenous individuals." UNDRIP art. 4 also mentions the obligation of both states and indigenous nations "to ensure that indigenous women and children enjoy the full protection and guarantees against all forms of violence and discrimination." In UNDRIP, art. 22(2).

3. Sharon McIvor explains: Aboriginal women in Canada do not enjoy rights equal to those shared by other Canadians. Since 1869, colonialist and patriarchal federal laws-most notably the Indian Act-have fostered patriarchy in Aboriginal communities and subjected Aboriginal women to loss of Indian status and the benefits of band membership, eviction from reserve home, and denial of an equal share of matrimonial property. Colonialism and patriarchy have also enabled cooperation between male Aboriginal leadership and Canadian governments to resist the inclusion of Aboriginal women in Aboriginal governance. These denials and exclusions perpetuate the exposure of Aboriginal women and their children to violence and consign many to extreme poverty." In Rauna Kuokkanen, "Self-Determination and Indigenous Women's Rights at the Intersection of International Human Rights", Human Rights Quarterly 34 (2012): 225-227, 233-234; Laura Parisi and Jeff Corntassel, "In Pursuit of Self-Determination: Indigenous Women's Challenges to Traditional Diplomatic Spaces", Canadian Foreign Policy 13 (2007): 81, 87.

4. The concept of 'intersectionality' has been defined as "intersectional oppression [that] arises out of the combination of various oppressions which, together, produce something unique and distinct from any one form of discrimination standing alone...." In Mary Eaton, "Patently Confused, Complex Inequality and Canada v. Mossop", Review of Constitutional Studies 1 (1994): 203-229.

5. A nearly ice-free Arctic Ocean in September before mid-century is likely. See Intergovernmental Panel on Climate Change (IPCC), "Human influence on climate clear, IPCC report says," ScienceDaily (September 2013): 18-23, www.sciencedaily.com/releases/2013/09/130927092341. htm (accessed February 14, 2014). See also, Lavanya Rajamani et al., Human rights and climate change: a review of the international legal dimensions (Washington, D.C.: World Bank, 2011), 1; Edward Cameron, Development, climate change and human rights: From the Margins to the Mainstream? World Bank Social Development Working Paper 123 (March 2011).

6. Kravchenko Svitlana, "Procedural Rights as a Crucial Tool to Combat Climate Change," Georgia Fournal of International and Comparative Law 38, 3 (October 27, 2010): 614. Available at http://dx.doi.org/10.2139/ssrn.1698828.

7. Center for International Environmental Law and Friedrich Ebert Stiftung, "Human Rights and Climate Change: Practical Steps for Implementation" (2009), 10. Available at http:// www.ciel.org/Publications/CCandHRE_Feb09.pdf (accessed June 15th, 2015).

8. Lavanya Rajamani et al., Human rights and climate change: a review of the international legal dimensions (Washington, D.C.: World Bank, 2011), 13; Elisabeth Caesens \& Maritere Rodríguez, Climate change and the right to food: a comprehensive study (Berlin: Heinrich-Böll-Stiftung, 


\section{T. Prior}

2009), 28; Climate change impacts, vulnerabilities and adaptation in developing countries, (Bonn, Germany: United Nations Framework Convention on Climate Change, 2007), 38.

9. Leena Heinämäki, The Right to Be a Part of Nature: Indigenous Peoples and the Environment (Rovaniemi: Lapin yliopistokustannus, 2010). Acta Universitatis Lapponiensis 180, 31.

10. IPCC, 2001; Caesens and Rodríguez, Climate change and the right to food: a comprehensive study, 25.

11. Cameron, "Development, climate change and human rights. From margins to the mainstream?", 17-18; UNFCCC, AWG-LCA (2010); Center for International Environmental Law and Friedrich Ebert Stiftung, "Human Rights and Climate Change: Practical Steps for Implementation" 8; Siobhán McInerney-Lankford, "Climate Change and Human Rights: An Introduction to The Legal Issues", Harvard Environmental Law Review., 33 (2009): 431; Leena Heinämäki, The Right to Be a Part of Nature: Indigenous Peoples and the Environment (Rovaniemi: Lapin yliopistokustannus, 2010). Acta Universitatis Lapponiensis 180, 1.

12. Duyck, Sebastien, Timo Koivurova and Leena Heinämäki, "Climate Change and Human Rights" in Climate Change and the Law, edited by Erkki J. Hollo, Kati Kulovesi and Michael Mehling (Berlin: Springer, 2012), 295.

13. These factors include financial wealth or poverty, differential livelihoods education, health, age, gender, sexual orientation, disability, indigeneity, minority status, governance, ethnicity, as well as social class and caste. McInerney-Lankford, "Climate Change and Human Rights: An Introduction to the Legal Issues", 431 \& 436; Marc Limon, "Human Rights and Climate Change: Constructing a Case for Political Action", Harvard Environmental Law Review, 33 (2009): 447-448; Arun Agrawal, The role of local institutions in adaptation to climate change (Washington DC: World Bank, 2008), 18; Nick Brooks, W. Neil Adger, P. Mick Kelly, "The determinants of vulnerability and adaptive capacity at the national level and the implications for adaptation", Global Environmental Change 15, 2 (2005): 153; World Health Organizations, "Gender, Climate Change and Health" (2011), 5. Available at http://www. who.int/globalchange/GenderClimateChangeHealthfinal.pdf (accessed June 15th, 2015). Cameron, "Development, climate change and human rights. From margins to the mainstream?”, 17-18; UNFCCC, AWG-LCA (2010); Center for International Environmental Law and Friedrich Ebert Stiftung, "Human Rights and Climate Change: Practical Steps for Implementation" (2009), 8; Leena Heinämäki, The Right to Be a Part of Nature: Indigenous Peoples and the Environment (Rovaniemi: Lapin yliopistokustannus, 2010). Acta Universitatis Lapponiensis 180,1 .

14. Human development report, International cooperation at a crossroads: aid, trade and security in an unequal world (New York: Oxford University Press, 2005).

15. Ricardo Hausmann et al., Global Gender Gap Report (Geneva, Switzerland:World Economic forum, 2009).

16. Kathleen Lahey, Eva-Maria Svensson, and Asa Gunnarsson, "Gender Challenges \& Human Capital in the Arctic.” In L. Heininen, H. Exner-Pirot, \& J. Plouffe (eds.) Arctic Yearbook (Akureyri, Iceland: Northern Research Forum): 1-17.

17. Liane Schalatek, Gender and Climate Finance: Double Mainstreaming for Sustainable Development (Washington DC: Heinrich-Böll-Stiftung North America, 2009); Liana Schalatek, Democratizing Financing for Sustainable Development: Gender Equality is the Key (Washington DC: Heinrich Böll Stiftung North America, 2012): 136. http://www.boell.org/downloads/ Schalatek_DemocratizingFinancing.pdf (last accessed: July 25, 2013).

18. UNDP, "Ensuring Gender Equity in Climate Change Financing” (2011): 8.

19. See Human Development Report, Fighting climate change: human solidarity rin a divided world (New York: United Nations Development Programme, 2007).

20. World Bank 2011, UNDP HDR 2011, Perch 2011, OECD 2008, Schalatek 2009, WHO and GGCA 2009; Food and Agriculture Organisation (FAO), "The State of Food and 


\section{The Rights and Role of Indigenous Women in The Climate Change Regime}

Agriculture" (2011); Stephan Klasen, "Gender, growth and adaptation to climate change" in Powerful Synergies: Gender equality, economic development and environmental sustainability, UNDP ed. (New York: UNDP, 2012), 60-61; see Rodenberg 2009: 11.

21. UNPD, "Overview of linkages between gender and climate change", Gender and Climate Change Capacity Development Series, Training Module 1 (Africa, 2012); Habtezion, Zerisenay, "Gender and Climate Change Africa", Policy Brief 1 (2011) http://www.undp.org/ content/dam/undp/library/gender/Gender\%20and\%20Environment/Gender\%20and $\% 20$ Climate \%20Change\%20Policy\%20Brief\%201\%20Final.pdf (last accessed: July 26, 2013).

22. Klasen, "Gender, growth and adaptation to climate change," 60-61.

23. Globally, only 8 percent of cabinet members and 19 percent of parliament members are women. Furthermore, women make up $17 \%$ of all seats in parliaments across the globe.

24. Eaton. "Patently Confused: Complex Inequality and Canada v. Mossop," 203-245, 229. See also, Carol Aylward, "Intersectionality: Crossing the Theoretical and Praxis Divide." Fournal of Critical Race Inquiry 1 (1) (2011): 1925-3850.

25. Survival International, "The Most Inconvenient Trust of All, climate Change and Indigenous People 1" (2009): 3. Available at: http://assets.survivalinternational.org/documents/132/survival_climate_change_report_english.pdf (last visited: March 29, 2013); “Global Warming Solutions are Hurting Indigenous People, Says U.N.”, mongabay.com, (2 April 2008), http://news.mongabay. com/2008/0402-redd_indigenous_people.html (last visited: March 29, 2013); For an overview of potential climate change implications, see M.L. Parry et al. eds., "Intergovernmental Panel on Climate Change, Climate Change 2007: Impacts, Adaptation and Vulnerability. Contribution of Working Group II to the Fourth Assessment Report of the Intergovernmental Panel on Climate Change" (2007): 7-22 http://www.ipcc.ch/publications_and_data/ar4/wg2/en/contents. html (last visited March 29, 2013); Duyck et al. "Climate Change and Human Rights", 301.

26. International Expert Group Meeting on Indigenous Peoples and Climate Change, $2 \mathrm{http}: / /$ www.un.org/esa/socdev/unpfii/documents/E_C19_2008_CRP_9.doc (last accessed March 29, 2013); Alan Parker et al eds., Climate Change and Pacific Rim Indigenous Nations, Executive Summary 23 (2006), available at http://academic.evergreen.edu/g/grossmaz/IndigClimate2. pdf (last visited: March 29, 2013).

27. John H. Knox, "Linking Human Rights and Climate Change at the United Nations," Harvard Environmental Law Review 33 (2009): 488-489; Survival International, The Most Inconvenient Trust of All, climate Change and Indigenous People 1 (2009), 3; Climate change has affected their rights and interests, especially with regard to cultural rights and their right to freely dispose of natural resources. Lankford et al., Human rights and climate change: a review of the international legal dimensions (Washington, D.C.: World Bank, 2011), 18; "'Climate Change' Forces Eskimos to Abandon Village” (28 April 2009) http://edition.cnn.com/2009/ $\mathrm{TECH} /$ science/04/24/climate.change.eskimos/index.html; Meanwhile, reindeer herders have reported declining animal populations because they find it increasingly difficult to access food. International Arctic Science Committee, "The Saami Community of Lovozero Climate Change Study Case", Arctic Climate Impact Assessment (2010), Available at http:// www.eoearth.org/article/Kola:_the_Saami_community_of_Lovozero_climate_change_case_ study. (last visited: March 29, 2013); Mark Nuttall et al., "Hunting, Herding, Fishing, and Gathering: Indigenous Peoples and Renewable Resource Use in the Arctic" in Arctic Climate Impact Assessment (Arctic Council, Scientific Reports, 2004); Duyck et al. "Climate Change and Human Rights".

28. Knox, "Linking Human Rights and Climate Change at the United Nations," 488-489.

29. Arctic Climate Impact Assessment (Arctic Council, Scientific Reports, 2004).

30. J. Eyzaguirre, "Climate change and Canada: an untapped opportunity to advance gender equality?" Canadian Women's Health Network 11, 1 (2009). hile some s hoods and rights. tapped opportunity to advance gender equality?" 


\section{T. Prior}

31. Cameron, "Development, climate change and human rights: From the Margins to the Mainstream?" 8.

32. Miranda L. Aponte, "Introduction to indigenous peoples' status and rights under international human rights law," in Climate Change and Indigenous Peoples: The Search for Legal Remedies, eds. Randall S. Abate and Elizabeth Ann Kronk (Northampton: Edward Elgar Publishing, 2013), 39.

33. Leena Heinämäki, The Right to Be a Part of Nature: Indigenous Peoples and the Environment (Rovaniemi: Lapin yliopistokustannus, 2010). Acta Universitatis Lapponiensis 180, 10-11.

34. The UNFCCC has highlighted the preservation of indigenous knowledge as an important element in determining adaptation options (e.g. gender-specific vulnerability assessments, community-level responses, coping strategies). Climate change impacts, vulnerabilities and adaptation in developing countries (Bonn, Germany: United Nations Framework Convention on Climate Change, 2007), 16.

35. Sheila Watt-Cloutier et al., with support of Inuit Circumpolar Council, Petition to the Inter-American Commission on Human Rights, Violations Resulting from Global Warming Caused by the United States (December 7, 2005).

36. Arctic Athabaskan Council On Behalf Of All Arctic Athabaskan Peoples Of The Arctic Regions Of Canada And The United States, "Petition To The Inter-American Commission On Human Rights Seeking Relief From Violations OfThe Rights Of Arctic Athabaskan Peoples Resulting From Rapid Arctic Warming And Melting Caused By Emissions Of Black Carbon By Canada", (23 April 2013). Available at: http://earthjustice.org/sites/default/files/AAC_ PETITION_13-04-23a.pdf. (last accessed on August 27, 2017).

37. Eaton, "Patently Confused, Complex Inequality and Canada v. Mossop", 203-229; An intersectional approach takes into account the historical, social and political context and recognizes the unique experience of the individual based on the intersection of all relevant grounds. In Aylward, "Intersectionality: Crossing the Theoretical and Praxis Divide"; This approach allows the particular experience of discrimination, based on the confluence of grounds involved, to be acknowledged and remedied. In Ontario Human Rights Commission, "An Introduction to the Intersectional Approach" http://www.ohrc.on.ca/en/intersectional-approach-discrimination-addressing-multiple-grounds-human-rights-claims/ introduction-intersectional-approach\#fn6; In Minority Rights Group International, "Gender, Our Work" http://www.minorityrights.org/6861/thematic-focus/gender.html

38. Ellen-Rose Kambel, “A Guide to Indigenous Women's Rights under the International Convention on the Elimination of All Forms of Discrimination Against Women" Forest Peoples Programme (2012), 7 ; Mona Ethienne and Eleanor Burke Leacock, Women and Colonization (Westport: Greenwood Publishing Group, 1980), 68.

39. "Declaration of the International Indigenous Women's Forum" adopted in New York at the Beijing +5 (2000).

40. Cameron, "Development, climate change and human rights. From margins to the mainstream?", 3-4.

41. Kravchenko, "Procedural Rights as a Crucial Tool to Combat Climate Change", 616.

42. See Caesens and Rodríguez, Climate change and the right to food: a comprehensive study, 15-39; McInerney-Lankford, "Climate Change and Human Rights" Harvard Environmental Law Review 33 (2009): 434; Rajamani et al., Human rights and climate change: a review of the international legal dimensions, 21.

43. Leena Heinämäki, The Right to Be a Part of Nature: Indigenous Peoples and the Environment (Rovaniemi: Lapin yliopistokustannus, (2010), 27; Daniel Bodansky, "Climate Change and Human Rights: Unpacking the Issues," Georgia fournal of International and Comparative Law 38 (2010): 8; Caesens and Rodríguez, Climate change and the right to food: a comprehensive study, 42 . 


\section{The Rights and Role of Indigenous Women in The Climate Change Regime}

44. Leena Heinämäki, The Right to Be a Part of Nature: Indigenous Peoples and the Environment (Rovaniemi: Lapin yliopistokustannus, (2010) Acta Universitatis Lapponiensis 180, 16 and 19.

45. Human Rights Council, Tenth Session, Resolution 10/4 on "Human Rights and Climate Change", see: http://bit.ly/12BH8fg; The resolution was supported by $88 \mathrm{UN}$ member states from various regions. Kravchenko, "Procedural Rights as a Crucial Tool to Combat Climate Change," 647.

46. Leena Heinämäki, The Right to Be a Part of Nature: Indigenous Peoples and the Environment (Rovaniemi: Lapin yliopistokustannus), (2010) Acta Universitatis Lapponiensis 180, 24 and 252-253; Malé Declaration, Human dimension of Global Climate Change (Malé, 14 November 2007); Knox, "Linking Human Rights and Climate Change at the United Nations", 477 and 486; World Health Organization, "The Social Dimensions of Climate Chance" (2011), 5.

47. The OHCHR, Understanding Human Rights and Climate Change, Submission of the Office of the High Commissioner for Human Rights to the 21st Conference of the Parties to the United Nations Framework Convention on Climate Change, 2015, at 4, Para 9, available at http://www.ohchr.org/Documents/Issues/ClimateChange/COP21.pdf.

48. Ibid.

49. The OHCHR, "Applying a Human Rights based approach to climate change negotiations, policies and measures”, available at: http://hrbaportal.org/wp-content/files/InfoNoteHRBA1. pdf.

50. United Nations, General Assembly, Report of the Special Rapporteur on the issue of human rights obligations relating to the enjoyment of a safe, clean, healthy and sustainable environment, $\mathrm{A} /$ HRC/31/52 (February 2016)

51. General assembly, A/HRC/31/52, part IV A (General Considerations), para 33.

52. General assembly, A/HRC/31/52, para 81; General assembly, Report of the Independent Expert on the issue of human rights obligations relating to the enjoyment of a safe, clean, healthy and sustainable environment $\mathrm{A} / \mathrm{HRC} / 25 / 53$, paras. 69-78.

53. General assembly, A/HRC/31/52, para 82 .

54. John Knox (The United Nations Independent Expert on human rights and environment, Office of the High Commissioner for Human Rights), "Environment and Human Rights: the link is there, and so is the State's obligation to protect them" (March 2013), http://www. ohchr.org/en/NewsEvents/Pages/DisplayNews.aspx?NewsID=13089\&LangID=E (accessed June 15 $\left.5^{\text {th }}, 2015\right)$.

55. Publications on this subject include, among others: R. Desgagne, "Integrating Environmental Values into the European Convention Human Rights", American fournal of International Law 89 (1995): 263-94; M. Thorme, "Establishing Environment as Human Right", Denver Fournal of International Law and Policy 19 (1991): 301; A. Boyle and M. Anderson eds., Human Rights Approaches to Environmental Protection (Oxford University Press UK, 1996); D. Shelton, "What Happened in Rio to Human Rights?", YBIEL 3 (1992): 75; D. Shelton, "Human Rights, Environmental Rights and the Right to the Environment", Stanford fournal of International Law 28 (1991): 103; A. Kiss and D. Shelton, International Environmental Law (Nottingham: Brill, 2004), 661-731; G. Handl, "Human Rights and Protection of the Environment: A Mildly 'Revisionist'View", in Human Rights, Sustainable Development and the Environment, A.A Cancado Trinidade ed. (Costa Rica: IIHR, 1992), 117; G. Handl, "Human Rights and Protection of the Environment", in Economic, Social and Cultural Rights: A Textbook, A. Eide et al. eds. (Netherlands: Nijhoff, 2001), 303; M. Fitzmaurice, "Some Reflections on Public Participation in Environmental Matters as a Human Right in International Law", Non-State Actors and International Law 2 (2002): 1; J. Hancock, Environmental Human Rights: Power, Ethics and Law (England: Ashgate, 2003); T. Hayward, Constitutional Environmental Rights (Oxford: Oxford University Press, 2005). 


\section{T. Prior}

56. See, for instance, Human Rights Committee, E.H.P. v. Canada, Communication No. 67/1980, UN Doc. CCPR/C/OP/1, (1984); Human Rights Committee, Lubicon Lake Band v. Canada, Communication No. 167/1984, CCPR/C/38/D/167/1984; European Court of Human Rights, Case of Öneryildiz v. Turkey, Judgement (2004) 41; European Court of Human Rights, Di Sarno v. Italy, 30765/08 (2012); Inter-American Court of Human Rights, Mayagna Awas Tingni Community v. Nicaragua, (Ser.C), No. 79 (August 2001); Inter-American Court of Human Rights, Saramaka people v. Suriname (Preliminary Objections, Merits, Reparations and Costs) (November2007).

57. Desgagne, "Integrating Environmental Values into the European Convention Human Rights", 263-4.

58. Brundtland, Gro-Harlem (ed.), "Our Common Future: Bruntland Report", The World Commission on Environment and Development (1987): 330. Tuula Kolari, The right to a decent environment with special reference to indigenous peoples: research report (Rovaniemi, Finland: University of Lapland, Arctic Centre, Northern Institute for Environmental and Minority Law, 2004).

59. OHCHR and UNEP, "Human Rights and the Environment - Rio +20, Joint Report OHCHR and UNEP” (Background Document) (2012), OHCHR-UNEP Joint Side Event, "Human Rights at the Center of Sustainable Development - Honoring Rio Principle 1", United Nations Conference on Sustainable Development Rio de faneiro, Brazil (19 June 2012): 36.

60. McInerney-Lankford, "Climate Change and Human Rights" Harvard Environmental Law Review 33 (2009): 431; Duyck et al. "Climate Change and Human Rights"; Leena Heinämäki, The Right to Be a Part of Nature: Indigenous Peoples and the Environment (Rovaniemi: Lapin yliopistokustannus, 2010), 27, 207-208.

61. World Health Organization, "The Social Dimensions of Climate Chance" (2011): 16. For a practical example, see: World Health Organization, Gender Mainstreaming for Health Managers: A Practical Approach. (Geneva: WHO, 2011).

62. OHCHR and UNEP, "Human Rights and the Environment - Rio +20: Joint Report OHCHR and UNEP" (Background Document) (2012): 35; OECD and DAC, Integrating Human Rights into Development: Donor Approaches, Experiences and Challenges (Paris: OECD, 2006).

63. Parisi and Corntassel, "In Pursuit of Self-Determination: Indigenous Women's Challenges to Traditional Diplomatic Spaces", 81.

64. A. Xanthaki," The UN Declaration on the rights of indigenous peoples and collective rights: What's the future for indigenous women," in Reflections on the UN Declaration on the Rights of Indigenous Peoples, eds. S. Allen and A. Xanthaki (Oxford: Hart Publishing, 2011): 413-432, 420-421. See, Yakin Ertürk, UN GAOR, Human Rights Council, "Intersections Between Culture and Violence Against Women, Report of the Special Rapporteur on Violence Against Women, Its Causes and Consequences", 4th Session, A/HRC/4/34 (2007), (Geneva: UN Documents, 2007), para. 68.

65. S. Radcliffe, "Indigenous Women, Rights and the Nation-State in the Andes" in Gender and the Politics of Rights in Latin America, eds. N. Craske and M. Molinaux (New York: Palgrave, 2012), 149, 16.

66. Radcliffe, "Indigenous Women, Rights and the Nation-State in the Andes" 16.

67. UN General Assembly, Universal Declaration of Human Rights (10 December 1948), 217 A (III), available at: http://www.refworld.org/docid/3ae6b3712c.html (last accessed: 26 July, 2013).

68. UN General Assembly, "International Covenant on Economic, Social and Cultural Rights", United Nations, Treaty Series vol. 993 (16 December 1966): p 3, available at: http://www.refworld.org/docid/3ae6b36c0.html (last accessed: $26 \mathrm{July}, 2013$ ). 


\section{The Rights and Role of Indigenous Women in The Climate Change Regime}

69. UN General Assembly, "International Covenant on Economic, Social and Cultural Rights", United Nations, Treaty Series vol. 999 (16 December 1966): p. 171, available at: http://www. refworld.org/docid/3ae6b3aa0.html (last accessed: 26 July, 2013).

70. CEDAW was adopted by the UN General Assembly on 18 December 1979 and has been ratified by 187 countries. Lorena Revelo and Itzá Camey, Resource guide on gender and climate change (New York, NY: United Nations development programme, 2008), 41; The 1979 Convention for the Elimination for all forms of Discrimination against Women (CEDAW) serves as a key link to other international human rights instruments in UNEP, "UNEP Gender Plan of Action" (2006): 3.

71. See Articles $2,7,8,14.1$.

72. I. Dankelman, "On the Road to Sustainable Development: Promoting Gender Equality and Addressing Climate Change," in UNDP, Powerful synergies: Gender Equality, Economic Development and Environmental Sustainability (New York: UNDP, 2012), 27.

73. CEDAW Committee, "Statement of the CEDAW Committee on Gender and Climate Change", 44th session, New York, 20 July - 7 August 2009, access at: http://unfccc.int/resource/docs/2009/smsn/igo/064.pdf.

74. Committee on the Elimination on the Discrimination of Women, "Half-day general discussion on 'gender-related dimensions of disaster risk reduction and climate change," United Nations Human Rights Office of the High Commissioner, February/March 2016. Available at: http://www.ohchr.org/EN/HRBodies/CEDAW/Pages/ClimateChange.aspx (last accessed: September 1, 2017).

75. CEDAW Committee, Concept note for the General Discussion on Gender-related dimensions of Disaster Risk Reduction and Climate Change, Para 5, p. 1-2., available at: http:// www.ohchr.org/Documents/HRBodies/CEDAW/ClimateChange/ConceptNote.pdf.

76. Timo Koivurova, et al.,"Arctic Indigenous Peoples and the Challenge of Climate Change" in Arctic Marine Governance: Opportunities for Transatlantic Cooperation, eds. Krämer and Cavalieri (Berlin: Springer, 2013); ILO (International Labor Organization) (1989).

77. Kuokkanen, "Self-Determination and Indigenous Women's Rights at the Intersection of International Human Rights," 231-232; Mairin Iwanka Raya, "Indigenous Women Stand Against Violence," A Companion Report to the United Nations Secretary General's Study on Violence Against Women 8, (2006).

78. Mary Sillett, "Ensuring Indigenous Women's Voices Are Heard: The Beijing Declaration of Indigenous Women" in First Voices: An Aboriginal Women's Reader, eds. Patricia A. Monture \& Patricia D. McGuire (Canada: Inanna Publications, 2009), 207-211.

79. Kuokkanen, "Self-Determination and Indigenous Women's Rights at the Intersection of International Human Rights”, 232; Mary Sillett, "Ensuring Indigenous Women's Voices Are Heard: The Beijing Declaration of Indigenous Women" in First Voices: An Aboriginal Women's Reader, eds. Patricia A. Monture \& Patricia D. McGuire (Canada: Inanna Publications, 2009), 207-211.

80. Kuokkanen, “Self-Determination and Indigenous Women's Rights at the Intersection of International Human Rights", 233.

81. Recommendations to the CEDAW Committee to guarantee to respect, enjoyment and implementation of the individual and collective rights of indigenous women, 2014, Para 3, available at: http://learnwhr.org/wp-content/uploads/CEDAW-Suggested-GenRec-IndigWomen-Draft.pdf.

82. UN General Assembly, "United Nations Declaration on the Rights of Indigenous Peoples: resolution / adopted by the General Assembly" A/RES/61/295 (2 October 2007). http:// www.refworld.org/docid/471355a82.html (last accessed: July 27, 2013).

83. UN General Assembly, "United Nations Declaration on the Rights of Indigenous Peoples: resolution / adopted by the General Assembly" A/RES/61/295 (2 October 2007). 


\section{T. Prior}

84. Ibid.

85. Ellen-Rose Kambel, $A$ Guide to Indigenous Women's Rights under the International Convention on the Elimination of All Forms of Discrimination Against Women (Moreton in Marsh: Forest Peoples Programme, 2012), 9.

86. The report was compiled by the Support Group members at the Forum on indigenous peoples and climate change (E/C.19/2008/10).

87. Revelo and Camey, Resource guide on gender and climate change, 50-51.

88. Kuokkanen, "Self-Determination and Indigenous Women's Rights at the Intersection of International Human Rights", 249.

89. C. Kukathas, "Are there any cultural rights?" Political Theory Vol 20 No 5 (1992) 16, 113; J. Donnelly, "Cultural Relativism and Universal Human Rights," Human Rights Quarterly 6 (1984): 400, 410-413.

90. Xanthaki, "The UN Declaration on the rights of indigenous peoples and collective rights: What's the future for indigenous women," 416.

91. Kuokkanen, "Self-Determination and Indigenous Women's Rights at the Intersection of International Human Rights", 225.

92. Ibid., 226.

93. Ibid., 247.

94. Kuokkanen, "Self-Determination and Indigenous Women's Rights at the Intersection of International Human Rights," 236.

95. Kuokkanen, "Self-Determination and Indigenous Women's Rights at the Intersection of International Human Rights”, 234-235.

96. Ibid, 235.

97. Kuokkanen, "Self-determination and Indigenous Women - 'Whose Voice Is It We Hear in the Sámi Parliament?", 59 .

98. Ibid., 57-58.

99. Lorena Aguilar, "Establishing the linkages between Gender and Climate Lorena Aguilar, "Establishing the linkages between Gender and Climate Change Adaptation and Mitigation," in Gender and Climate Change, ed. Irene Dankelman (New York: Routledge, 2011), 73; Dankelman, "On the Road to Sustainable Development: Promoting Gender Equality and Addressing Climate Change," 48.

100. The Kyoto Protocol was developed with the objective of reducing GHG emissions by $5 \%$ between 2008 and 2012. It includes three flexible mechanisms "designed to reduce the costs of compliance with emission reduction targets: the Clean Development Mechanism (CDM); the Joint Implementation (JI); and Emissions Trading."

101. Gender advocates have, however, actively engaged in negotiation processes.

102. Organisation for Economic Co-operation and Development, Gender and sustainable development, "Maximising economic, social and environmental role of women" (2008); IPCC, Climate Change: 2007, 729-730.

103. CEDAW Committee, Statement on Gender and Climate Change (adopted at the $44^{\text {th }}$ meeting, New York, 20 July to 7 August, 2009).

104. Nordic Council of Ministers, "Gender and climate change" (Copenhagen, 2009): 12.

105. See Dankelman, "On the Road To Sustainable Development: Promoting Gender Equality and Addressing Climate Change".

106. Schalatek, Democratizing Financing for Sustainable Development: Gender Equality is the Key.

107. Dankelman, "On the Road To Sustainable Development: Promoting Gender Equality and Addressing Climate Change, 45.

108. See: "Rahoituspäätös: Tuki Global Gender and Climate Alliancen (GGCA) hankkeelle naisten roolin vahvistamiseksi ja sukupuolinäkökulman valtavirtaistamiseksi globaalissa ilmastopolitiikassa” (2012-2014) - Ulkoasiainministeriö: Kehityspolitiikka.”Ulkoasiainministeriö, 


\section{The Rights and Role of Indigenous Women in The Climate Change Regime}

access at: http://formin.finland.fi/public/default.aspx?contentid=241498\&contentlan=1\&culture=fi-FI (last accessed: July 26, 2013); See also: "COP 18 adopts a decision promoting gender balance in climate change negotiations | UN Women, "UN Women - Headquarters" http://www.unwomen.org/2012/12/cop-18-adopts-a-decision-promoting-gender-balance-in-climate-change-negotiations/ (last accessed: July 27, 2013).

109. See Gender Day at COP 19, "Global Gender and Climate Alliance" (October 7, 2014) from http://www.gender-climate.org/Events/Gender-Day-at-COP19.php; and The Environment and Gender Index (EGI) "The Environment and Gender Index (EGI)" (October 7, 2014) from http://environmentgenderindex.org.

110. See "Gender \& Climate Change", Draft conclusions proposed by the Chair, UNFCCC/ SBI/2013/L.16, Thirty-ninth session Warsaw, 11-16 November 2013.

111. See UN Women, "Women for results: climate change initiatives highlighted at COP-19" (October 7, 2014) http://www.unwomen.org/en/news/stories/2013/11/gender-days-at-cop19

112. See: Gender Climate Change: http://www.gendercc.net/policy/conferences/warsaw-2013. html.

113. Stella Gama, Priyanka Teeluck and Janna Tenzing, Strengthening the Lima Work Programme on Gender, Perspectives from Malawi and CBD, Issue Paper, October 2016, IIED, p. 4., available at: http://pubs.iied.org/pdfs/10165IIED.pdf

114. 18/CP.20.

115. See, Stella Gama, Priyanka Teeluck and Janna Tenzing, Strengthening the Lima Work Programme on Gender, Perspectives from Malawi and CBD, 2016, 6.

116. FCCC/CP/2016/10/Add.2, Plenary Session, 17 November, 2016.

117. Ibid., Preamble.

118. FCCC/SBI/2016/10.

119. Revelo and Camey, Resource guide on gender and climate change, 51 .

120. Ibid., 46-47.

121. Ibid., 46-47.

122. The Paris Agreement opened for signature on 22 April 2016. It entered into force on 4 November 2016, 30 days after the so-called "double threshold" (ratification by 55 countries that account for at least $55 \%$ of global emissions had been met).

123. FCCC/CP/2015/10/Add.1.

124. Ibid, Para 102.

125. See WEDO, "Women's Participation in UN Climate Negotiations: 2008-2012" (2012) http:// www.wedo.org/wp-content/uploads/WomenUNFCCCParticipation2008-2012FINAL2013. pdf (last accessed: July 27, 2013).

126. WEDO, "Women's Participation in UN Climate Negotiations: 2008-2012".

127. FCCC/CP/2012/8/Add.3. Promoting gender balance and improving the participation of women in UNFCCC negotiations and in the representation of Parties in bodies established pursuant to the Convention or the Kyoto Protocol.

128. See, Stella Gama, Priyanka Teeluck and Janna Tenzing, 2016, p. 10.

129. FCCC/CP/2016/4. See, ibid.

130. $\mathrm{FCCC} / \mathrm{CP} / 2016 / 4$.

131. Ibid.

132. FCCC/CP/2016/4, 6 .

133. R.L Barsh, "Indigenous Peoples", in The Oxford Handbook of International Environmental Law, eds. D. Bodansky, J. Brunnée and E. Hey (Oxford: Oxford University Press, 2007), 850.

134. L. Heinämäki, "Rethinking the Status of Indigenous Peoples in International Environmental Decision-Making: Pondering the Role of Arctic Indigenous Peoples and the Challenge of Climate Change" in Climate Governance in the Arctic, Environment \& Policy, Vol. 50, eds. T. Koivurova, E.C.H. Keskitalo and N. Bankes (Netherlands: Springer, 2009), 223. 


\section{T. Prior}

135. Timo Koivurova and L. Heinämäki, "The Participation of indigenous peoples in international norm-making in the Arctic," Polar Record Vol.42 (221): 102.

136. International Covenant on Civil and Political Rights, UN Doc A/6316 (1966), adopted 16 December 1966, entered into force 23 March 1976, 999 UNTS 171, International Covenant on Economic, Social and Cultural Rights, UN Doc. A/6316 (1966), adopted 16 December 1966, entered into force 3 January 1976, 993 UNTS 3.

137. International Convention on the Elimination of all Forms of Racial Discrimination, adopted 7 March 1966, entered into force 4 January 1969, 660 UNTS 195.

138. Indigenous peoples' participation in the climate change regime is currently supported by the Observer Organizations Liaison Office of the UN climate secretariat.

139. Report of the Subsidiary Body for Implementation on its twentieth session, FCCC/ SBI/2004/10, para 109.

140. Arrangements for intergovernmental meetings. Note by the Executive Secretary, FCCC/ SBI/2011/6, para. 46.

141. Decision 1/CP.16, The Cancun Agreements: Outcome of the work of the Ad Hoc Working Group on Long-term Cooperative Action under the Convention, UN Doc. FCCC/ CP/2010/07/Add.1, para 8 (15 March 2011).

142. FCCC Dec 1/CP.16, Appendix 1.2(c).

143. "The Inari Declaration on the occasion of the Third Ministerial Meeting of the Arctic Council" (10 October 2002).

144. The concept of 'intersectionality' has been defined as "intersectional oppression [that] arises out of the combination of various oppressions which, together, produce something unique and distinct from any one form of discrimination standing alone...." In Eaton, "Patently Confused, Complex Inequality and Canada v. Mossop", 203-229.

145. Kuokkanen, "Indigenous Women's Rights,” 241.

146. Kuokkanen, "Indigenous Women's Rights,” 242.

147. AHDR, Arctic Human Development Report (Akureyri: Stefansson Arctic Institute, 2004), 187.

148. AHDR, Arctic Human Development Report, 187.

149. Lorena Aguilar, "Linking Gender and Climate Change", IUCN and GGCA.

150. McInturff further underlines that, in small communities, it is often difficult for women to run for positions of leadership against male relatives (e.g. Nunavut). Furthermore, negotiating relationships in small communities may be particularly difficult when certain persons hold more than one position and there is, for instance, little distinction between government representatives and civil society. Notes from a presentation by Kate McInturff, "Mapping the Future" in Conference on "Gender, Law, and the Arctic" (paper presented at University of Umea, Sweden, May 5-8, 2013).

151. Rauna Kuokkanen, "Indigenous Women in Traditional Economies: The Case of Sámi Reindeer Herding," Fournal of Women in Culture and Society 34, 3 (2009): 501.

152. Stakeholder Consultation with Lorena Aguilar. Interview with the author.

153. Arctic Council is an intergovernmental organization between Arctic States with the aim of environmental protection. Indigenous Peoples' Organizations have gained a status of permanent participants, which allows them to be present, and to make proposal and statements in all the decision-making of the Council.

154. L. Heinämäki, "Rethinking the Status of Indigenous Peoples in International Environmental Decision-Making: Pondering the Role of Arctic Indigenous Peoples and the Challenge of Climate Change" in Climate Governance in the Arctic, Environment \& Policy, Vol. 50, eds. T. Koivurova, E.C.H. Keskitalo and N. Bankes (Netherlands: Springer, 2009).

155. M. Lindroth, "Indigenous-state relations in the UN: establishing the indigenous forum", Polar Record 42 (2006): 239-248, at 246. 
156. United Nations Permanent Forum on Indigenous Issues. Statement by the Arctic Caucus Inuit Circumpolar Council and the Saami Council, presented by Patricia Cochran, Chair, Inuit Circumpolar Council, $7^{\text {th }}$ Session (New York, 21 April to 2 May 2008).

157. United Nations Permanent Forum on Indigenous Issues. Statement by the Arctic Caucus Inuit Circumpolar Council and the Saami Council, Item 1.

158. Although it excludes an option for secession, UNDRIP strongly protects internal aspects of self-determination, such as the right to self-government.

159. Leena Heinämäki, "Towards an Equal Partnership between Indigenous Peoples and States: Learning from Arctic Experiences?," The Yearbook of Polar Law Vol. 3 (2011): 193-246.

160. Bartolome Clavero, "The Indigenous Rights of Participation and International Development Policies”, Arizona fournal of International \& Comparative Law 22 (2005): 41.

161. The United Nations Collaborative Programme on Reducing Emissions from Deforestation and Forest Degradation in Developing Countries, The Business Case for Mainstreaming Gender in REDD+ (United Nations Development Programme, United Nations Environment Programme, and Food and Agriculture Organization of the United Nations, 2011), 6.

162. UNDP, UNEP, and FAO, "The Business Case for Mainstreaming Gender in REDD+", UN-REDD Programme (2011), 25.

163. UN-REDD Programme, "The Business Case for Mainstreaming Gender in REDD+" (2011), UNDP, UNEP, and FAO, 6.

164. AHDR, Arctic Human Development Report, 189.

165. Ibid., 201.

166. Kuokkanen, “Self-Determination and Indigenous Women's Rights at the Intersection of International Human Rights", 237.

167. The concept of 'intersectionality' has been defined as "intersectional oppression [that] arises out of the combination of various oppressions which, together, produce something unique and distinct from any one form of discrimination standing alone..." In Eaton, "Patently Confused, Complex Inequality and Canada v. Mossop”, 203-229. 